\title{
The Legal Protection of Forests: Ethiopian Green Legacy vs. International Environmental Regimes
}

\author{
Abebe Kebede Jalleta \\ Law School, Research Institute of Environmental Law, Wuhan University, Wuhan, China \\ Email: abekebjalle@gmail.com
}

How to cite this paper: Jalleta, A. K. (2021). The Legal Protection of Forests: Ethiopian Green Legacy vs. International Environmental Regimes. Beijing Law Review, 12, 725-749. https://doi.org/10.4236/blr.2021.123038

Received: June 18, 2021

Accepted: July 23, 2021

Published: July 26, 2021

Copyright (อ 2021 by author(s) and Scientific Research Publishing Inc. This work is licensed under the Creative Commons Attribution International License (CC BY 4.0).

http://creativecommons.org/licenses/by/4.0/

\section{(c) (i) Open Access}

\begin{abstract}
An international forest sustainability treaty is essential to encourage states to work for restoration and minimize the loss of existing forests. However, such a treaty is unlikely despite the many efforts of different actors, including UN organizations. Due to these barriers, this article analyzes the interconnection and integration among some International Environmental Law instruments including, but not limited to: The Rio-Conventions along with their associated protocols and soft laws. It employed combinations of evaluative and comparative approaches to identify forest issues clearly in definitions, objectives, and existence of target specific goals, integration of laws and practices, and improvements made on forest quality and quantity. As a result, the instruments have minimum legal bases for state parties' cooperation to enhance forest gain and minimize forest loss. However, they face paradox of convergence and divergence, added to their incompleteness and fragmentation.
\end{abstract}

\section{Keywords}

International Environmental Law, Deforestation, Degradation, Forest Restoration, Rio-Conventions, Ethiopian Green Legacy

\section{Introduction}

Unprecedented environmental disruptions constitute a significant threat worldwide. Efforts to counter them through a comprehensive global legal regime and to maintaining Land Degradation Neutrality (LDN) in general and forest conservation and protection, in particular, have taken decades (Eikermann, 2015). Despite many influences through continuous international dialogues and scho- 
larly work, no consensus has been reached to alleviate threats to forest resources at international and national levels (Maguire, 2013; Eikermann, 2015).

International Environmental Law (IEL) based cooperation is key to maximize forest services and reach the intended LDN. Publicists and works of academics' advice for multilateral cooperation in management and conservation of natural resources that have transboundary impacts guided by the principles of "common but differentiated responsibilities (Ferreira, 2016)". Collaboration in regulatory measures and compliance in actions, such as forest governance, enables managing environmental challenges like climate change and greenhouse emissions (Peeters and Eliantonio, 2020). Such mutual measures in environmental resource conservation like forest are said to be critical to benefit from their services (UN, 2015). However, diverse views, laws, and practices related to man's actions challenge such aspirations. The variations begin with diversified definitions given to the term: "forest" which stems from the diversity of the forest itself and forest ecosystem at international, national, and community levels (CBD, 1992). But cooperation needs contextualized definitions to protect, maintain, and restore forest resources for the intended purposes (Chazdon et al., 2016). Because contextualizing such depictions foster national and global policies in these regards (Ibid.). Varying views and practices are among the causes of discrepancy in the type and status of the international legal regime on the forest.

Agenda 2030 and SDG15.2 provide the vitality of international law and win-win cooperation in bringing actors together to regulate forest gains and losses (Agenda 2030, 2015: Para. 18). IEL is a tool that guides and obligates actors and states' varying mandates, capabilities, circumstances, unilateral and collective commitments towards achieving their goals of cooperation (The New York Declaration on Forests, 2014). However, multiple treaties may not be equally important in this regard. Some international instruments comply and reinforce each other. But others may pay less attention to reforestation or afforestation or sustaining the existing forest. This article analyses some IEL instruments to identify the global legal bottom line in obliging cooperation to reforestation or afforestation to maintain LDN. Among many, it emphasizes the Rio-Conventions namely the United Nations Convention to Combat Desertification (UNCCD, 1994), the Convention on Biological Diversity (CBD, 1992), and the Framework Convention on Climate Change (UNFCCC) along with their associated protocols and soft laws including, the World Heritage Convention's $(\mathrm{WHC})^{1}$, the Convention on Wetlands (Ramsar Convention, 1971), Convention on International Trade in Endangered Species of Wild Flora and Fauna (CITES) ${ }^{2}$ and the International Tropical Timber Agreement (ITTA).

It is organized as follows: the second section highlights the forest ecosystem's roles in meeting LDN and the threats targeted at them following this introduc${ }^{1}$ United Nations Convention Concerning the Protection of the World Cultural and Natural Heritage (WHC, Adopted 17 November 1972, Entered into Force 17 December 1975) 1037 UNTS 151. ${ }^{2}$ Convention on International Trade in Endangered Species of Wild Fauna and Flora, Washington DC, 3 March 1973, in force 1 July 1975, 993 UNTS 243. 
tory section. This section helps to seek legal solutions taking mindful of the two extremes. Section three analyzes the legal bottom line of forest governance in general and the restoration of the lost forest. The examination helps to understand the legal basis for mandatory cooperation in international, regional, and domestic legal situations relating to forest resources governance. Section four addresses the global and domestic implementation of forest provisions under IEL and cooperation options among neighboring state parties to this effect. It discusses implementing forest regimes somewhere compared to Ethiopia's domestic legal and actual enforcements. The section also evaluates the scalability of the Ethiopian "Green Legacy" initiative, which has been implemented since 2019 and is planned to distribute one billion saplings to six neighboring countries out of seven billion seedlings prepared for the 2021 summer season. The number of prepared seedlings to each country in millions are as follows: Djibouti nine, Eritrea 29, Kenya 386, Somalia 129, South Sudan 91, and Sudan 316 (Ethiopian Broadcasting Corporation (EBC), 2021). Section five concludes with recommendations.

The article employed combinations of methodologies (Hoecke, 2013; Morgera, 2015). It used evaluative and comparative approaches to identify forest issues clearly in definitions, objectives, and existence of target specific goals, integration of laws and practices, and improvements in forest quality and quantity. Also, state and UN agencies' reports, scholarly works of literature, international and domestic laws, good state practices on reforestations were consulted to enrich this work.

\section{Forest Services and Threats: International and Domestic Contexts}

Different jurisdictions and the international legal arena adopt various definitions of forests based on their coverage area, ecological, social, and economic services (Brunnee \& Dwasi, 2006). For example, the forest is a $20 \%$ canopy covering a minimum of 0.5 hectares of land in the European Union (Ibid.). In comparison, this amount is reduced to $10 \%$ in the Mediterranean region and "the Food and Agriculture Organization of the United Nations (FAO)" definition (Ibid). Some national laws define it more broadly where small forest fragments join the huge vegetation. For instance, Article 2 (1) of the Ethiopian forest law defines it as: "...trees, plants and other biodiversity accumulation at and in the surrounding of forestlands, roadsides, riversides, farm, and grazing lands as well as residential areas, parks that grow naturally or developed in some other ways" 3 . This national definition includes forestland that comprises many fauna and flora species and an area covered with trees (Ibid, Article 2(4); Brunnee \& Dwasi, 2006). These meanings lead us to understand forest ecosystems, encompassing areas with dense tree coverage of any species, including rainforests, tropical, boreal, temperate, wetland, and grassland found in all ${ }^{3}$ Proclamation No. 1065/2018, Forest Development, Conservation and Utilization Proclamation, Negarit Gazette, $24^{\text {th }}$ year no 21, Addis Ababa, 23 January 2018, Article 2(1). 
geographic areas (Maguire, 2013). And forests can be defined contextually starting from the minimum quantity upwards along with its services.

The forest ecosystem gives many services to humans and nature, including but not limited to fuel, non-wood forest products; soil and water protection; "protection of fragile ecosystems (mountains, drylands, and small islands)"; biodiversity conservation; climate change mitigation/carbon sequestration; other economic and socio-cultural values and services (Eikermann, 2015). For example, it protects the environment by regulating climate processes and climate change (Ministry of Environment, Forest and Climate Change (MEFCC), 2017). Forests maintain the quantity, quality, and regular water flow; store carbon in their organs and soils, including absorbing atmospheric carbon dioxide to keep climatic balances and prevent atmospheric disruption (Brunnee \& Dwasi, 2006). As they usually grow on mountains and elevated areas, forests also prevent soil erosion (MEFCC, 2017). Economic-wise, a forest accelerates the economic development of a state in general and hosts wildlife in particular (Ibid). Forests are sources of medicine, food, a dwelling place for humans and wildlife for a long (Sommer, 2020). Mainly, indigenous people and other rural communities' livelihood, social-cultural, and spiritual manifestations are based on forest products (Asfaw \& Etefa, 2017). Economists estimate that more than one-fourth of the income in rural communities comes from natural forests (Ibid).

However, forests face two primary threats: deforestation and forest degradation, although the threat varies among economic clusters (Eikermann, 2015). Deforestation is about converting forestland into another land use. Still, degradation is "changes within the forest which negatively affect the structure or function of the stand or site thereby lowering the capacity to supply products and services" (Forest Biodiversity, 2006). In both cases, forest loss occurs when the amount of the forest becomes less than the defined unit or terms, for example, $10 \%$ (Ibid). In developing countries like Africa, drivers of deforestation include commercial and subsistence agriculture, infrastructure (dams, water reservoirs, roads), mining, and urbanization (UNCCD, 2019a).

In contrast, most of the degradation is driven by timber extraction and logging, fuelwood collection, and charcoal production, uncontrolled livestock grazing (Hosonuma et al., 2012). For instance, infrastructure construction-related activities account for $9 \%-17 \%$ of tropical and sub-tropical deforestation (REDD+ Ethiopia, 2021; The New York Declaration on Forests, 2019). A study found that commodity-driven deforestation became a reason for "tree loss in Latin America (59\%) and south-east Asia (80\%)" during 2016-1018 (Heflich, 2020). Besides, pastoralists and hunters ignite fire into the forest to get fresh grazing grass for their herds and to kill wild animals for food. The fire instigates atmospheric disruption due to carbon emission (a report from Abe-Dongoro district [unpublished], 2017).

Forest loss through these drivers impacts the forest services, as mentioned earlier. Reduced biodiversity, increased GHG emissions, disruption of water cycles, increased soil erosion, and disrupted livelihoods are among the impacts 
of forest loss (WWF, 2021). A study shows that soil erosion impacts $52 \%$ of land by taking away its healthy soil used for food production following removing trees from a landscape (IUCN, 2021). This problem, in turn, adversely affects 1.6 billion livelihoods of the global people, of which one billion are the poorest of all (Ibid). Thus, out of the two threats, land-use change-based deforestation with the motive to achieve Sustainable Development Goals (SDGs) using natural resources contributed the lion-share to the imbalance between forest gain and loss in developing countries (Eikermann, 2015). Forest gain deals with a restoration that brings back the amount at least to the minimum forest level described in the definitions above.

While there have been recorded increases in forest cover in the developed world and some northeast Asian countries, forest loss continues in developing countries in general and tropical forest areas. However, the insufficiency of scientific information and unequal distribution of technology makes it difficult to measure actual quality (degradation) and the deforested quantity of forests (Eikermann, 2015: p. 21). In this regard, FAO argues that the rate of forest loss declined to -0.08 from -0.18 between the years $2010-2015$, where it was in 1990 (MEFCC, 2017). It reasons that planting 110 million hectares (ha) of trees, which is about $7 \%$ of the world's forest area, contributed to protecting further loss (MEFCC, 2017). Nonetheless, the 2018 study of this organization shows that the world loses about 13 million ha of natural forests every year, while the problem is still severe in the global South's tropical countries and the Boreal zone of Eurasia in the Global North (MEFCC, 2017). This number has increased by three million from the 1990s, ten million losses every year (Eikermann, 2015: pp. 22-23). The world forest cover diminished drastically from 6.2 billion (ha) or $47 \%$ of the earth in 8000 years and a study conducted in 1996 revealed that deforestation consumes 10 million (ha) per year.

Consequently, 25 countries faced total loss, while 29 countries remained only with $10 \%$ of their forest cover and developing countries lost 65 million hectares within 1990-1995 (Ibid). For instance, Ethiopia lost 70,000 (ha)s, while it gained 30,000 (ha)s per year during the years 2000-2013. However, the 2015 state report indicates an increase of forest cover from seven percent from the late 1990s to 14 percent in 2013 (Ethiopian National Planning Commission, Central Statistical Agency (hereafter, NPC \& CSA, 2017). Since then, forest loss has grown to 91,000 (ha) since then every year (Climatekos gGmbH, 2020). The primary reasons for these problems are the human encroachments and contemporary environmental challenges that limit the global forest cover not to surpass $30 \%$ (Sotirov et al., 2020). The imbalance between the replaced and lost forests coupled with the global nature of forest loss impacts, the need to enhance forest services, and the complexity of scientific and technological knowledge on forest conservation impelled regulations of deforestation/degradation and forestation measures in cooperation. The question is whether there is a legal basis to oblige this collaboration. The next sections address this issue. 


\section{An Appraisal of the Legal Bottom-Line of Forest Protection}

An international legal bottom-line of forest governance that emphasizes preventing deforestation and encouraging reforestation is one means of tackling land degradation. This section analyzes the needs, efforts, and challenges of adopting a comprehensive international forest regime before evaluating the regional and Ethiopian national legal regimes. The global frameworks and contexts help understand regional and domestic legal situations.

\subsection{The Legal Divergence and Convergence Paradox}

The need to regulate forests is related to its services and threats, as discussed in the preceding section (Eikermann, 2015: pp. 28-29). The primary rationales of forest legislation at the national level in earlier stages are utilization motive, population growth, and importance to human well-being (Ibid). Advancement of technology and knowledge revealed invaluable ecosystem services and functions, which have transboundary impacts, and necessitated legally binding international norms to avail such benefits to all worldwide at later times (Ibid). Accordingly, interests to adopt a common policy and international forest law boldly came into being since the 1992 Rio Convention on Environment and Development (Braatz, 2003), while no legally binding instrument has been developed yet (Sommer, 2020: pp. 7-10). Diverse views, preferences of actors on forest use, and political resistance of states to protect their sovereignty from alien intervention account for the lack of an identified treaty.

States' resistance to a comprehensive agreement stems from economic, selfprotection and complexity of management perspectives. On the one hand, most states prioritize the economic benefits they yield from the forest over its ecological benefits (Sotirov et al., 2020). Particularly, some developing countries oppose such holistic law suspecting industrialized countries' undue influence on the management of their forests using a treaty as a tool, which they think has adverse socio-economic consequences in the tropics (Ibid). And thus, they were not interested in subjugating their sovereign power of national forest control to global authority (Ibid). Also, some argue that historically, the industrialized nations developed themselves using their colonies' natural resources other than their own without any limit (Ibid). Therefore, when it comes to emerging economies' disposal of owned wealth to development, the current suspicion of international legislation shouldn't be surprised. Nonetheless, all nations should consider implementing the IEL they ratified either unilaterally or through cooperation when utilizing their resources (Agenda 2030, 2015: Para. 18). Preferably, the joint effort is critical to save our earth against the negative impacts of deforestation and meet LDN (Ibid, Para. 49-53, SDG15.3).

On the other hand, some raise different reasons that made a one binding forest law impossible or prefer soft laws instead of treaties. Ben Boer justifies it as: "...complex nature of international law-making in these fields, [...] confusing and sometimes conflicting approaches among the various institutional actors, ... di- 
verse nature of the fields involved, and the diverging priorities and focuses of most of the organizations" (Boer, 2016). Another line of argument is that gradual compliance and mutual support of environmental protection and climate change mitigation policies and difficulty in reaching and easily dissolving international agreements seem to prolong a forest convention (Schroeder, 2010). Peeters and Eliantonio argue that diversity in regulations helps seek optimal solutions in specific domestic circumstances and support stricter implementation (Peeters \& Eliantonio, 2020: p. 481). At the same time, their critics are related to more efforts to understand and apply multifaceted regulations and the latter's unproven effectiveness to achieve environmental goals (Ibid). Indeed, merger of treaties may result in shortage of state parties to the anticipated forest law. The same problem may happen as some countries went out of a few binding laws like the Kyoto protocol and the 2015 Paris Agreement on Climate Change (PA), arguing that they unduly induce them (Leitner, 2011: p. 177). Surprisingly, there is no certainty on the contributions of soft laws to succeed in proper environmental protection yet (Peeters \& Eliantonio, 2020: p. 481). Consequently, the fragmentation of international forest laws continues with a very limited effect on reducing forest loss (Sommer, 2020: pp. 6-8).

Some treaties perceive, define and provide forest governance provisions only in terms of the objectives they are provided for instead of considering the general services of forest in its "private and public good" capacity. This approach forgets the basic importance of forests and denies them the legal protections they deserve. Article 1 of the Ramsar convention considers issues of forests if they are designated as wetlands fulfilling the definitional requirements of the wetlands of international importance, such as wet fowls' habitat. And according to Article 2 of this treaty, each state party shall enlist such an area for consideration based on set criteria for selection, the importance of which could be in terms of ecology, botany, and hydrology. Once a forest is designated as a wetland, it benefits from protection and conservation provided under articles 3,4 , and 5 of this law by acquiring the nature reserve status.

Similarly, a forest becomes the subject of IEL and gets protection under the WHC if it meets the requirement of "an outstanding universal value" under the WHC, Article 1. In a net shell, Forests' services are in line with article 2 of this convention. They are 'habitat for threatened species of animals and plants; their natural features have aesthetic and scientific importance; and they are universally crucial to the sustenance of life, natural beauty of the ecosystem, and in situ conservation of the overall biological diversity, including their economic importance to the state parties of the WHC (Article 2). Likewise, the Convention on International Trade in Endangered Species of Wild Flora and Fauna (CITES) accords protection to a forest that hosts about 5800 animals and more than thirty-thousand plant species that form forest parts provided under indexes (Fobar, 2019). However, transacting some forest species is allowed among the lists protected by this convention that exacerbates the dangers of their extinction (CITES, Article IV and Appendix II). 
The other extreme legal divergence comes from the International Tropical Timber Agreement (ITTA) that treats forests in their commodity value. According to Article one of the treaty, the entire purpose of ITTA is timber trade. To achieve this objective, article 1(i) (j) provides for forest's sustainable management, ecological balance, and protection of local communities' interests depending on forest resources. Although some provisions provide for reforestation and rehabilitation of degraded land to fulfill these interests, the rationale of all these duties is to encourage forest trade rather than address other forest services and preserve it for future generations (Sommer, 2020). Whatever reasons are attached to the entire purposes of ITTA, allowing wood trade by the treaty reinforces reduction and threatens the survival of the forest ecosystem, especially in developing countries.

On the contrary, the Rio conventions (the CBD, UNFCCC, and UNCCD) converge and are interconnected on protection and conservation of the terrestrial resources. Success in the primary focus of the UNCCD-land management and restoration is vital to achieving one of the $\mathrm{CBD}$ rationales-reduction or loss of biodiversity (CBD, preamble \& Article 1). Mainly, it helps to reduce habitat loss and degradation, sustainable farming and forestry, and the ecosystem restoration aims provided under the Aichi targets number 5, 7, and 14. At the same time, land restoration rehabilitates forests, which is critical for reducing GHG emissions and enhancing "climate change adaptation, addressing the objectives of the UNFCCC and the Nationally Determined Contribution (NDC) implementation" (Climatekos gGmbH, 2020). In this sense, LDN is alike with emission neutrality, meaning one of the UNCCD objectives converges with UNFCCC [and the CBD] (emphasis added, Ibid). The former considers deforestation as one of the severe causes of desertification (UNCCD, Article 10). And the latter, including its implementing instrument, the Kyoto protocol, covers forest protections for its uses in carbon sinking and sequestration capacities (United Nation's Climate Change, 2021). The protocol provides obligatory targets on reducible gas through forest protection and conservation (Kyoto protocol, Articles 2.1 (a) (iii) and 3(3)). But, whether the Rio conventions fully address the forest services is still debatable.

One can observe many unaddressed values of forests that necessitate a comprehensive international binding law that consolidates and holistically regulate forest issues from these IEL instruments. For instance, no convention directly addresses other forest services like medicinal and human shelter (Sommer, 2020: pp. 2-7). However, one may apply the CBD provisions to conserve an ecosystem containing some plant species that use as medicine, which indirectly helps forest conservation (CBD, Article 15). Yet, contradictory objectives of these international laws continue to be a challenge to forest protection. Sommer also argues that the "absence of a global forest convention, unachievable goals, and a general lack of political will" is among many challenges to governing forest resources effectively (Sommer, 2020: p. 12). Thus, these challenges delayed the efforts of different actors, including UN organizations, to solve the IEL paradox: convergence and divergence among the treaties discussed. 
It has been a long time since negotiations on forest law began and remained without coming to terms. They usually end up with the proliferation of policy documents and declarations (Boer, 2016). An international forest treaty is important to induce states to work for restoration and minimize loss of the existing forest. Soft laws like the Rio Declaration on the Environment and Development (1992), forest principles (UNGA, 1992), and Chapter 11 of Agenda 21 also play a critical role in the coordination and exchange of information among nations on sustainable forest management (Boer and Hannam, 2021). The "United Nations Forum on Forests (UNFF)" has frequently been trying to develop a legally binding instrument through the Intergovernmental Panel on Forests (IPF) and Intergovernmental Forum on Forests (IFF) Processes, including other basic international forest policy (Sotirov et al., 2020: p. 4). Likewise, efforts of UNEP to ease the fragmentation of forest provisions and lack of coherence or integration of approach among laws relating to water, forests, soils, and the marine environment through its institutions and sponsored programs, such as Program for the Development and Periodic Review of Environmental Law (the Montevideo Program), hasn't become fruitful due to its limited legal status and lack of political influence (UNEP, 2015). A similar trend continued on the international environmental pact debates leaving aside the intended convention and inclining to policy documents (Ruiz, 2020).

However, the 2017 revised African Regional Convention on the Conservation of Nature and Natural resources (ARCCNN) ${ }^{4}$ complied with and attempted to compose forest provisions in different IEL treaties discussed so far, though it has some limitations (Article VI-IX). It addresses services of forest scattered in CITES, CBD, and the Ramsar conventions. Nonetheless, while emphasizing the vitality of vegetation to sustain water, soil, and species existence, it does not mention the climate mitigation role of forests. This convention creates duties upon state parties to take plan-based forest governance under the title: "vegetation cover conservation," including provisions on landed resources like land, soil, water, and species protection and conservation (ARCCNN, Articles VI-IX). Although it provides for the duty of rehabilitating, which could be in line with restoration or remediation of the degraded area to regain the lost forest, it doesn't establish accountability on the deforestation agents. Particularly, Article VIII reads:

"The parties shall take necessary measures to protect, conservation, sustainable use, and rehabilitation of vegetation cover. To this end, they shall: a) adopt scientifically-based and sound traditional conservation, utilization, and management plans for forests, woodlands, rangelands, wetlands, and other areas with vegetation cover, taking into account the social and economic needs of the people concerned, the importance of the vegetation cover for the maintenance of the water balance of an area, the productivity of soils and the habitat requirements of species;

b) take concrete steps or measures to control fires, forest exploitation, land

${ }^{4}$ The Revised African Convention on the Conservation of Nature and Natural Resources, 07 March 2017, Addis Ababa. 
clearing for cultivation, grazing by domestic and wild animals, and invasive species;

c) establish forest reserves and carry out afforestation programs where necessary;

d) limit forest grazing to season and intensities that will not prevent forest regeneration."

In short, the fragmented provisions of forests continue to function, raising issues of their effectiveness in stopping deforestation on one hand and forest restoration on the other hand. The next section deals with this issue.

\subsection{Legal Integration on Deforestation vis-à-vis Reforestation and the State Practice}

The essence of global forest governance depends upon the scope and purposes of the conservation and rehabilitation/restoration provisions provided under these treaties and practical implementation by the state parties at the domestic level. Sommer argues that fragmented IEL provisions effectively reduce forest loss, though their relative effect is very limited (Sommer, 2020: p. 8). This section analyses the integration of forest provisions in IEL to stop deforestation and enhance restoration and the necessity of the legal bottom-line on forest governance.

Convergence of the Rio conventions strengthens and synergizes the restoration of degraded land components. The CBD complements UNFCCC and UNCCD through its Aichi targets to reduce at least half or bring to zero forest loss and conserve biodiversity, including restoring degraded ecosystems and contributing to climate change mitigation and combat desertification (CBD, Aichi targets 5, 7, 14 \& 15). For instance, target 15 reads: “By 2020, ecosystem resilience and the contribution of biodiversity to carbon stocks has been enhanced, through conservation and restoration, including restoration of at least 15 percent of degraded ecosystems, thereby contributing to climate change mitigation and adaptation and to combating desertification." Although this target fails to mention the term: "rehabilitation" and specific ecosystem to be restored (AkhtarSchuster et al., 2017), the cumulative reading with target 5 indicates that it can jointly function with the UNCCD, while the UNFCCC has explicit rehabilitation provision that enables it joint implementation with the UNCCD (UNFCCC, Article 4 (e)).

However, these conventions have some gaps that question their effectiveness. They emphasize on impacts of land degradation on the ecosystem and its protection/prevention of land and resource degradation, while restoration of the degraded ones is given less attention (Altvater et al., 2015). On this point, a report claims: "restoration/remediation is critical to effectively implement the LDN [...] by counterbalancing land degradation that happens regardless of prevention actions" (Ibid). For instance, the UNFCCC and its Kyoto protocol have no direct provision on remediation of degraded resources. Still, it introduces large-scale reforestation and rehabilitation through REDD+ projects to reduce 
GHG emissions, which is not legally binding (UNCCD, 2019a). While the goals of the REDD+ are accepted and endorsed by state parties to the PA in their climate action plans, it lacks indemnifying the potential adverse effects on local communities with insecure tenure (UNCCD, 2019a). Also, the practicability of incentive schemes used by REDD+ is debatable (The PA, Article 5(2); Sommer, 2020: p. 6). Despite inspiring to establish environmental justice (Maguire, 2013: pp. 313-318), its entire targets rest on emission reduction, which can also be achieved through other means. And thus, the incentive scheme lacks a holistic purpose (Sommer, 2020: p. 6). Measures and targets such as emission trading, clean development, and joint implementation provided under the Kyoto protocol (2012-2020) were also ambitious to reforestation/afforestation. For instance, the set targets for industrialized 14 nations like the E.U. haven't been achieved yet, for which the latter proposed to extend the green deal to 2050 while reporting the progress so far (Peeters, 2020). While the life span of the protocol ended just soon after it entered into force, it needs amendments or some other solutions (Ibid). The absence of prevention provision opens to uncontrolled utilization by states and forest owners that calls for legal limits.

Conservation or rehabilitation provisions may not properly prevent or replace the loss of some non-restorable resources. Loss of wetlands or registered forest as a heritage invalidates the Ramsar and CITES following lack of deforestation preventing provisions of their limited objectives (CBD, Articles 8 (f), Rasmar, Article 3; WHC, Articles 4, 5, \& 6(2)). For instance, it is common to see large-scale development activities adversely impacting [forest] heritages that undermine the efficacy of the WHC (Boer \& Gruber, 2012). Besides, one of the objectives of the ITTA provides for reforestation and rehabilitation of degraded land to fulfill local communities' interests depending on forest resources and sustainable use of forests and ecological balances, the rationale of all these duties is to encourage forest trade rather than addressing other services of the forest (ITTA-2006, Article $1(\mathrm{j})(\mathrm{m})$ ). But the rationale of all these duties is to encourage forest trade rather than addressing other forest services (ITTA, preamble; Altvater et al., 2015: p. 14). Unlike the other two, the UNCCD has no amendments option through additional protocols that impede its dynamism to integrate with other laws. Thus, these laws, too, miss comprehensive provisions to govern the forest resources properly.

On the contrary, the ARCCNN looks comprehensive in integrating protection, conservation, rehabilitation, and sustainable use duties, including procedural rights of the public in this regard. For instance, it explicitly obliges states to protect against degradation and take necessary conservation and rehabilitation measures to the extent of reforming the existing agricultural and pastoral practices through activities like forestry (ARCCNN, Article VI (3) (b)). Furthermore, it links land, water, soil, and forest conservations to enforce one another as they converge and cross-impact each other (ARCCNN, Articles VI (3) (b) (ii), Article VII (2) (c)). However, while providing public participation from inceptions of natural resources use and rehabilitation/conservation duties, including public 
access to information, prior informed consent, and access to justice, the convention lacks indicators and standards to evaluate the successes in these rights. Also, there is no option for adopting the additional protocol to it in cases of amendments are required lest annexes, which are limited to scientific, technical, financial, and administrative matters (ARCCNN, Article XXXII). Such gaps impose difficulty in the implementation of the IEL.

From the actual enforcement perspective, the hitherto world practice of national states in upgrading their forest ecosystem through forestation did not bring significant difference except in a few countries like South Korea, Germany, New Zealand, and the UK (Leitner, 2011). Surprisingly, some state parties fail to properly replace their lost forest in advance or after their development plan consumes it. For example, Ethiopia is a state party to the WHC. Therefore, it has the right to benefit from registering its many forests that can meet heritage requirements also bears duties to fulfill provisions $4 \& 5(\mathrm{~d})$ of the convention. However, it didn't designate any of its forest reserves with landscapes of regional, national and international importance except the Yayu forest biosphere, which was registered in 2010 as a world heritage (WHC, Article 3; UNESCO, 2010). But nowadays, the Yayu forest is under threat of extinction by deforestation for coal mining and fertilizer industry followed by illegal settlements (Asfaw \& Etefa, 2017). The need for unauthorized land-use changes in the area is another challenge like other country's forest resources (ibid). The global institution in charge of implementing the convention would have induced the Ethiopian government to replace the lost forest had there been a provision allowing it to do so. This fact shows that evaluating the effectiveness of these treaties in the absence of provisions governing forest restoration leads to a haphazard conclusion. However, the current trend exhibits opposing scenarios of afforestation and deforestation in Ethiopia.

The national forest legislation and reforestation campaigns have become inline with the Rio conventions and the PA since 2019 (PA, Articles 6 \& 8 (4) (h)). On the other hand, it has been practically planting tree saplings to meet global climate change mitigation commitments, protect drought and desertification, and attain food security from fruit-yielding trees to contribute to sustainable

Table 1. Green Legacy plantation records.

\begin{tabular}{|c|c|c|c|c|c|c|c|c|}
\hline & \multicolumn{3}{|c|}{ No. of trees in billions } & \multicolumn{2}{|c|}{ Planted million/day } & \multicolumn{3}{|c|}{ Public participation in million } \\
\hline & 2019 & 2020 & 2021 & $2019 / 7 / 30$ & $2020 / 7 / 30$ & 2019 & 2020 & 2021 \\
\hline Plan & 4 & 5 & $6(7)$ & 200 & 300 & 15 & 20 & 25 \\
\hline Achieved & 4.7 & 5.9 & - & 353 & 412 & 20 & 23 & \\
\hline Growth rate & $84 \%$ & $88 \%$ & - & 84 & 88 & \multirow{2}{*}{\multicolumn{3}{|c|}{$\begin{array}{l}\text { Public participation, leadership } \\
\text { commitment, and institutional } \\
\text { coordination are increasing and } \\
\text { are the reasons for the success. }\end{array}$}} \\
\hline Remark & $\begin{array}{l}\text { The si } \\
\text { plan, } n \\
\text { One bi } \\
\text { to six } r\end{array}$ & $\begin{array}{l}\text { cess o } \\
\text { ile eac } \\
\text { on sap } \\
\text { ghbor }\end{array}$ & $\begin{array}{l}\text { planting } \\
\text { year's p } \\
\text { ngs fron } \\
\text { g count }\end{array}$ & $\begin{array}{l}\text { has been } \\
\text { an increases } \\
\text { the } 2021 \mathrm{pl} \\
\text { ies. }\end{array}$ & $\begin{array}{l}\text { re than the } \\
\text { one billion } \\
\text { will be sent }\end{array}$ & & & \\
\hline
\end{tabular}

Source: Ethiopian Broadcasting Corporation (EBC, 2021). 
development (Wassihun, 2020). Table 1 above shows the Ethiopian Green Legacy (EGL) successive achievements through public participation.

Accordingly, four billion tree saplings were planned where 4.7 billion were planted between May and October 2019, including those 353 million trees planted on a single day on July 30, 2019 (Wassihun, 2020). As a result, the number of trees planted in 2020 increased to more than five billion (Ibid). The government's report shows that the country's forest cover has been increased since the state has begun this campaign (Ibid). Public participation has also increased in tree planting where 20 and 23 million people planted 4.7 and 5.9 billion trees in 2019 and 2020 (EBC, 2021). This achievement broke the world record held by India, which involved 1.5 million people planting 66 million trees within a day (Ibid). Legislation-wise, the 2018 national forest law obliges the state and other actors to engage in forest development and conservation (Proclamation No. 1065/2018, Article 19). However, as will be discussed under section four, the law lacks clear provisions on stopping deforestation and restoring the lost ones.

On the other hand, development projects and other human activities sacrificed forests without replacing them, affecting their desired services severely. However, some countries have been trying to afforest and reforest their lands to increase carbon sink and get rewarded (Sotirov et al., 2020: p. 6). Deforestation conducted through forest burning, land-use change, and degradation creates dangers of carbon dioxide sink, which results in a no reduction of allowed carbon emission and reduce other forest services (Ibid). For example, situations before 2017 in Ethiopia justify this argument. Forest covering 54,200 hectares (ha) lands were between 2004 and 2016 in Chewaka resettlement village, without replacement in Ethiopia (Yilak and Debelo, 2019). In March 2021 alone, more than six national parks faced forest fires, destroying more than 40,000 ha of forest from each park (Abera, 2021). Also, the Ethiopian government cleared off natural forest cover on more than 300,000 ha of land for eight sugar cane plantations and industries since 2010 (Ethiopian Sugar Corporation, 2021). And forest covering 4854 ha of land will be cleared for the reservoir filling of the Grand Ethiopian Renaissance Dam (GERD) shortly other than the 1000 ha cleared in 2020 (Asrat, 2020; Ethiopian Monitor, 2021). Such scenarios necessitate legal regimes that require the actors to plant at least equivalent trees at the domestic level. In this regard, Ethiopia reformed forest laws in 2018 and has launched the Green Legacy campaign as of $2019^{5}$.

In other words, development motive reduces forest cover, which challenges implementations of the PA that obliges state parties to set their national commitments on conservation and appropriate sinks and reservoirs of greenhouse gas, including forests (Sotirov et al., 2020). Development induced forest loss that out-ways forest gains failing to counterbalance the ecosystem loss, and climate change mitigation indicates unsuccessful enforcement of IEL (NYDF, 2020). Mainly, swindling way of international law implementation activities can be a ${ }^{5}$ Proclamation No. 1065/2018, Forest Development, Conservation and Utilization Proclamation, Negarit Gazette, 24th year, no. 21, Addis Ababa, 23rd January 2018; Infra note section 4.2. 
challenge to maintain global warming increase below $1.5^{\circ} \mathrm{C}$ as agreed under the PA with each country's plan (PA, Article 2 (1) (a)).

Failure to succeed in increasing amounts of the forest also stems from gaps of domestic laws to include historical and customary attachments of indigenous people to their forests (Glover, 2020). The difference in perception of forest ownership between the state and the local community is reflected in state forest laws (Ibid). Most state laws provide forest as the sole property of the state, and the latter entrust it to others' custodianship, while the people perceive collective entitlement over forestland (Maguire, 2013). Especially indigenous people's collective ownership of forests has legal recognition under international human rights law and practically proved in deforestation reduction (Urbancic, 2020). However, increased pressure on land has been triggering their eviction and obstructing their livelihood that hinders them from conserving the forest (Ibid). Notably, state dominance over their ancestral forestland made the indigenous people reluctant to protect the forest against domestic migrants' illegal settlement and continued deforestation (A report from Abe-Dongoro district of Oromia, 2017, unpublished, filed with the Author). Some of them even tend to make charcoal and make money from burning wood instead of protecting it as they used to do.

Besides, communities' lack of participation in decision-making is another cause of forest deterioration. States, actors, and timber companies are duty-bound to consider the concerns of indigenous people and ensure their right of participation in the decision-making process on the fates of forests they used to administer (UNDRIP, Article 18). This duty shall also be implemented in bilateral agreements (Ibid). But timber companies rarely consider the views and livelihoods of indigenous people lest their involvement is demanded to share benefits from forest exploitation in Africa (Glover, 2020: p. 51). The global project of the UK on illegal logging and the UK-Indonesia bilateral action plan, too, bypassed the involvements of the communities who depend on forests (Ibid). Significantly, the action plan lacks a planned engagement of the local community to secure their livelihood. The results of such omission kill the communities' sense of ownership and distort state-public cooperation in resource conservation. States organs are remote to properly implement their international law duty of forest protection unless they involve the indigenous people's "wisdom which indirectly contributes to reducing carbon emission" (Urbancic, 2020). To this end, a 2014 study of eighty-forested areas in ten countries from East Africa, Latin America, and South Asia showed that forests under community ownership and management better-stored carbon than other conservation mechanisms (Stevens et al., 2014).

In summary, IEL instruments do not sufficiently provide for conservation and restoration of forests, although the Rio-conventions better reinforce each other to cover the legal gap. But the fragmentation of laws is apparent. Also, practical implementation varies from country to country and region to region. While 
there are efforts to restore forests learning from the risks of deforestation, still legitimate cooperation is pressing to enhance forest cover further and stop deforestation. The next section analyzes the legal rooms and Ethiopian domestic experience to cooperation among state parties to IEL.

\section{Sub-Regional Cooperation under IEL and Potential Lessons}

Achieving forest regaining targets and bringing difference would be difficult with the transboundary nature of negative impacts of forest loss unless uniform measures in restoration and land use and land-use changes are taken among neighboring countries. Such measures could be achieved through a legally binding agreement that creates cooperation among countries. In this regard, there is an initiative to scale up the Ethiopian Green Legacy (EGL) campaign to neighboring countries. This section analyses the existence of a legal basis for bilateral/multilateral cooperation in IEL and the legal source of the EGL at the Ethiopian domestic level and options of scaling up it to neighboring countries.

\subsection{Is There Legal Basis to Cooperate on Reforestation among Countries in IEL?}

Environmental protection, including forest, is a global issue beyond geographic or politically limited areas of sovereign states' jurisdiction (Maguire, 2013). Some research works argue that the depth and complicated nature of interconnection among ecosystems cover vast regions for extended periods (Ibid). This linkage makes sustainable forest governance a complex task calling for an integrated approach and common efforts among state parties to IEL (Ibid., p. 86). Without prejudice to their sovereignty, the existing international instruments oblige or encourage state parties to jointly address forest and other transboundary natural resource conservation issues to benefit from their services and prevent adverse impacts. For example, while deforestation forces shift their site from solid law enforcement and forest preventing state to the state with the weak police force to engage in similar deforestation, an impact of deforestation in a locality of one country disseminates carbon emission to its neighbor (Leitner, 2011). These problems call for joint forestry measures to tackle obstacles and learn from each other in ecosystem conservation activities.

In this context, the IEL treaties, as mentioned earlier, provide for bases of cooperation among state parties. For instance, Article 5(2) of the Ramsar convention obliges that state parties shall support, consult and cooperate concerning the conservation of wetlands. As stated in section three above, while it is specific to wetlands in its purpose and reaches, this convention recognizes forests as parts of the wide flora. But this duty doesn't bind non-state parties to this convention. As Ethiopia, Eritrea, and Somalia are not parties to it, as opposed to other African nations, they can implement provisions of this treaty through political deal (Ramsar, 2021). Article 6 (1) of the WHC also obliges member states 
based on the request from the affected country or an initiative to cooperate to conserve resources subject to the convention.

More importantly, the Rio-conventions could be jointly applied together to sustainable use of and tackle complex land degradation challenges in general and forest restoration and conservation in particular (UNCCD, 2021). As stated earlier, the "dynamics of land, climate, and biodiversity are intrinsic to one another. The conventions oblige state parties" individual or concerted efforts either through bilateral or multilateral cooperation or combined arrangements (UNCCD, Articles 4 - 6; CBD, Articles 5, 17 \& 18; UNFCCC, Article 4 (1)). Such legal collaborations are mutually supportive of each other, and they are guided by the principles of sovereignty, no harm, participation, equity, and common but differentiated responsibilities. For example, the UNFCCC provides for cooperation through common but differentiated responsibilities and respective capabilities to address problems of climate change through economic growth. At the same time, the PA also encourages the same joint efforts (PA, preamble, Articles, 5(2) 2(2)).

The principle of common but differentiated responsibilities is key to mitigating the potential climate changes jointly and individually by preventing deforestation and increasing the number of forests that can absorb atmospheric carbon (PA, Articles, 2(2)). Normative content and political leadership implications enshrined in this principle might be the legal basis for the actual cooperation (Ferreira, 2016). It guides them to come to terms to enhance the promotion and sustainable forest management, including protection and rehabilitation of affected areas by floods, droughts, and desertification in their respective sovereign boundaries. In addition, countries shall cooperate on technical, financial, information exchange, and training areas (UNFCCC, Articles 4(1) (d \& e), and 4(2) (a)). To this effect, countries can adopt common policies and assist each other on climate change mitigation strategies that encompass the protection of land degradation and deforestation (Ibid).

The 2030 SDGs affirm states' commitment to comply with their duties of the Rio-conventions. Goal 15 (3) of the SDGs reads: 'Protect, restore and promote sustainable use of terrestrial ecosystems, sustainably manage forests, combat desertification, and halt and reverse land degradation and halt biodiversity loss.' The first two targets of this goal emphasize forest, wetlands, mountains, and drylands conservation, restoration, and sustainable use (SDGs 15 (1) \& (2)). Thus, there are applicable legal bases in IEL concerning the duty to collaborate on LDN, climate change mitigation, and biodiversity conservation. At the same time, there should be common and private/unilateral legislative and policy measures to do so.

In addition, the success of collaborative duty in forest recovery bases on combinations of robust funding or government spending, public servants' commitment, and public environmental awareness (UNCCD, 2019b; UNCCD, Articles 1(f) \& 11). The 2018 UNCCD case studies on Northeast Asia show that actual 
implementation at the local community level and flows bottom-up and strengthens national and sub-regional integrations (UNCCD, 2019b). For example, the Republic of Korea's (ROK) forest rehabilitation, Mongolia's green wall, and China's compulsory tree planting national programs programs are designed and implemented in conformity with the UNCCD and UNFCCC (Ibid). These countries learned from their severe deforestation history and reforested their degraded land both unilaterally and cooperatively (Ibid). Mongolia's and China's forestry laws also provide a fixed campaign date for tree planting, and the ROK played a significant role in funding and technically supporting Mongolian afforestation efforts (Ibid). The cross-controlling and monitoring legal mechanism among local states/communities concerning the survival rate of planted trees also positively influenced the greening of assigned land to forests in the ROK (Ibid). As a result, China upgraded its forest cover from $8.6 \%$ in 1949 to $20.36 \%$ in 2019 (Ibid). The Korean republic also became the world model by greening $30 \%$ of its country including making the reforestation industry one of the sources of income (Ibid).

The legal norm for planting equivalent or more trees in advance to replace the numbers to be cut closes the gaps of forest loss or ecological disturbance in the meantime and helps LDN. Moreover, natural and social science studies show that forestation programs sustain holistic forest services and economic benefits of actors though preserving the existing ones are also emphasized following development induced degradation and deforestation's threat to the life on earth (Lee et al., 2018). In this regard, the UNFCCC and the PA have a sense of forestation before deforestation takes place. The respective provisions of these instruments indicate this direction from the "sustainable management ... enhancement ... of sinks and reservoirs of GHG...", which could be possible through adding the number of forest cover to the existing ones (PA, Article 5(1); UNFCCC, Article 4 (1) (d)). Furthermore, the preventive measures through precautionary principles laid under general obligation in the ARCCNN also imply continuous forestation to transfer livable ecosystems to the future generation (ARCCNN, Article IV). This duty is provided under Article VIII (1) (c) of the convention.

However, most of the practices seem reactionary, while some regions have become successful in restoring forest ecosystems, as revealed from the North-East Asian countries good practices discussed above (UNCCD, 2019b). Some states couldn't learn from them and usually conduct more severe deforestation using development purposes as an excuse exposing their land and soil to erosion, floods, and hurricanes that might damage heritage resources, including forests, resulting in transboundary responsibilities (WHC, Article 6(2)). But forestation in one country also benefits neighboring and downstream nations whose survival depends upon the upstream country's landed resources like waters which necessitates cooperation among such countries.

Deforestation is one of the East-African region's challenges that exacerbate 
dissertation and poverty (UNCCD, 2019a). The African context, too, needs similar efforts like the North-East Asian practice in tree planting. Therefore, scaling up their experiences combining with self-practice is worthy in implementing the ARCCNN (Wassihun, 2020). The following section analyzes Ethiopia's domestic forestation practice and the EGL's legal base, including its scalable potential to achieve the country's effort in this regard.

\subsection{A Lesson from Ethiopia's Green Legacy and Its Replicability}

The history of Ethiopia's Forestry campaign has a legal basis from the very beginning, unlike some other states' executive resolutions or political decisions. For example, the 1981 Chinese green movement was merely based on the political resolution and was effective until the 1984 Forest Law of the People's Republic of China (Forest Law of China, 2019). This law has been followed by successive amendments (Ibid, preamble). However, participatory tree planting and management in Ethiopia were regulated in the 1980 forest and wildlife proclamation that repealed the 1965 laws of the state, private and protective laws (Proclamation No. 192/1980, Preamble, Articles 3 (1)). This law was issued to halt the then drought and deforestation through mass mobilization Ibid, preamble). After that, the national forestry program was launched and implemented through campaign and labor selling to food for work (Ayana et al., 2018). But as it was not participatory in which prior and informed consent (PIC) of the people was not considered, including the property rights of those involved in forest restoration, it was criticized for lack of public trust and genuine engagement (Ibid).

The state then took a series of legislative and policy reforms that changed the complete state-owned resource to co-governance and complied with its international commitments. It domesticated the treaties it ratified by constitutionalizing and adopting proclamations and regulations to implement them (FDRE constitution, Articles 9(4) \& 13(2)). The 1995 Ethiopian constitution explicitly recognizes environmental rights as inseparable issues from human and development rights (FDRE constitution, Articles 43 \& 44). Regarding recognition of procedural rights, article 43(2) provides that "[n]nationals have the right to participate in national development and, in particular, to be consulted with respect to policies and projects affecting their community". Further, access to justice is expressly provided under article 37 of the constitution. The government also issued forest policies and strategies to implement its constitutional duty to "ensure that all Ethiopians live in a clean and healthy environment" including obligations not to damage the environment in its "design and implementation of programs and projects of development" (Article 92). The 2007 forest policy directions aim at regaining forest loss to combat desertification and drought (Ministry of Agriculture, 2007). Ethiopia issued new forest development program in 2017 that complies with and implements the country's commitment to the 2030 sustainable development agenda in general and SDG13-climate action 
and SDG15-life on land (MEFCC, 2017).

The 2018 forest proclamation was promulgated to bind the global commitments and rights enshrined in the constitution and policy directives. It addresses individual, communal, association, and state-owned forests (Proclamation No. 1065/2018, Preamble, and Article 4). This law aims at increasing the actors in forest development and conservation activities. Also, it promotes the active participation of the community in the state-owned forest development and management and benefits from the forest products (Ibid., Articles 12(3), 13(3)).

This legal guarantee contributed to practical implementation of the SDGs, while the green movement has begun to realize economic benefits and other services to the public. For instance, Ethiopia has been trading carbon which started with the Humbo community-based forest management project that yielded $\$ 34,000$ through REDD+ for the first time and in 2021 it also reaped 149 million Birr as a result of reducing deforestation and polluting gases in Bale and west Oromia (ENA, 2021). Particularly, the forest law encourages the unemployed and the indigenous/local community to engage in forestation through many incentive schemes (Proclamation No. 1065/2018, Articles 5, 7, \& 9). In this regard, it recognizes the irreplaceable role of indigenous people and local communities in managing the existing forest (Ayana et al., 2018: pp. 315-318).

Consequently, it categorizes the state forest into productive, protected, and preserved forests (Proclamation No. 1065/2018, Article 11). Production forests are developed for economic purposes; the protected ones are meant for different ecosystem services (Ibid, Article 2 (11) (13)). They shall be "utilized per a forest management plan developed by the responsible body without affecting the sustainability of the forest ecosystem value" (Ibid., Articles 2(11), (13), $12 \& 13$ ). The preserved forest is prohibited from human and domestic animal encroachment, and it is kept for the "... conservation of biological diversity, historical and research purposes" (Ibid, Articles 2 (12) \& 14). However, while listing the rights and duties of the forest owners, no provision specifies owners of trees to be planted by campaigns like the EGL.

The EGL campaign has been conducted on any bare land selected for forest plantation regardless of the identified title deed to the forested area. The EGL is a campaign that mobilizes millions of citizens during the rainy season to plant billions of seedlings and saplings. Institutions and their employees are responsible for the care and growth of the trees, while the same duty rests on the general public as a group on the land assigned to it (Ibid, Articles 19 (5)). Although there is no explicit mention of newly planted forest owners in the law, one can construe Articles 5 - 15 of the recent forest law in relation to the land tenure on which the trees have been planted to identify potential owners. For instance, trees planted in the compound of an industrial park belong to the park and are governed as state forests, though government employees or the public can do the planting activities. Likely, trees planted by employees of a state institution or private company on mountains, or water-shades, or any land assigned for the 
campaign belongs to the local state or the nearby community. While a regional or federal institution's employees cannot claim ownership and share of benefits from that forest as they didn't acquire the land in their name for forestry purposes, they are responsible for conserving, protecting, and watering the trees planted in their institution's name (Ibid, Article 6 (7)).

The EGL and the preceding forestation campaigns in Ethiopia have successfully complied with the objectives of the SDGs15 and the Rio-conventions (SDGs, preamble; UNCCD, Article 2). The previous mass mobilization and other initiatives covering more than 42,760 ha of land contributed to LDN, significantly increasing the "volume of water reaching downstream catchments and their groundwater" that might be a domestic lesson to the EGL (Allen et al., 2020). A report indicates that by the end of 1986, the forestation campaign covered 181,000 ha of land reforested, including about 500,000 ha of farmland and 175,000 ha of the hillside with various soil and water conservation structures (EBC, 2021). Trees planted during 2019-2021 and those anticipated in the plans to reach the twenty billion trees through EGL campaigns will deliver similar services where their governance is guided by explicit and coherent law (Ibid). Most planted trees are edible to foster food security goals and are indigenous to enhance carbon sequestration capacities (Ibid). This practice can be scaled up to countries like Sudan, where accumulated environmental issues exist due to anthropogenic and climatic or cyclic events through cooperation (Glovers, 2020). Therefore, the EGL has a domestic law base that complies with Ethiopia's commitments to the Rio conventions and their associated protocols (the global Bonn Challenge and the New York declaration) and the African (AFR100) restoration targets by increasing the number of trees by 2024 (Ibid., Preamble; Gashaw, 2021).

The EGL also meets the scope of the regional convention, which mandatorily extends activities undertaken in one jurisdiction to the other without prejudice to the sovereignty of state parties (ARCCNN, Article 1). Article 1(2) of the ARCCNN reads: "this convention shall apply to the activities carried out under the jurisdiction or control of any party within the area of its national jurisdiction or beyond the limits of its national jurisdiction" (Ibid). One can infer from this provision that campaigns to regain forests welcomes neighboring countries, and their fruits positively impact such countries. Also, it obliges allies to enhance their policies, legislations, and IEL convention's effectiveness (ARCCNN, Article 1). Hence, the EGL can be scaled up under the auspices of the ARCCNN and the MEAs' scopes of application and enforcement mechanisms.

\section{Conclusion}

Operationalizing the conservation, sustaining, and restoration of forest resources necessitate an IEL that can be a basis for cooperative tasks among countries. The analysis in this article shows the existence of a legal bottom-line in the existing IEL that either obliges or encourages state parties to jointly enhance the world's 
forest cover through technical, financial, and any means of collaboration and achieve these objectives. Some instruments are mutually supportive and enable the endeavor to bring the forest service back. The Rio conventions and the PA have provisions upon which countries' cooperation should emanate. However, these and other treaties are highly fragmented and limited to the specific objectives of their creation, posing limited impacts on stopping deforestation and enhancing forest restoration.

In addition, practices of the Northeast Asian countries are good lessons for collaboration in reforestation, while the reality on the ground in most developing countries contradicts their IEL commitments. Successful reforestation requires stronger economy, stricter forestry laws, committed public servants, increased government spending, and increased environmental awareness at national and sub-regional levels. But, equally, the government's policy initiatives and commitments to mass mobilization and creating institutional framework play a pivotal role in the success of these inputs (UNCCD, 2019c). Empowering the local community and building their sense of ownership enable better implementations of the forestation campaigns through the bottom-up flow of forest governance. The role of the national and sub-regional states should also be awareness-raising, providing inputs and technical supports. Thus state parties to the forest-related conventions should reduce deforestation and join each other in conservation and rehabilitation measures to be up to their commitments.

The Ethiopian massive forestation practice is scalable and has an IEL basis though it didn't reach LDN by restoring the lost forest. At the same time, the implementation of forest law also didn't attain zero deforestation yet. The law is incomplete as it doesn't provide for obligatory restorations. The annual campaigns also should include the move that halts deforestation practices. Therefore, the EGL can be transplanted as policymakers will base on cooperation regimes provided under the Rio conventions and the PA.

\section{Acknowledgements}

The author gratefully acknowledges Professor Qin Tianbao, Professor Otto Spijkers, Dr. Jemie Sommer and the anonymous reviewers for their constructive comments on the early draft of the manuscript.

\section{Conflicts of Interest}

The author declares no conflicts of interest regarding the publication of this paper.

\section{References}

Abera, E. (2021). Ethiopia: Multiple Forest Fires Result of Arsonists: Says Forest Conservation and Preservation Director. Addis Standard. https://allafrica.com/stories/202103310955.html

Agenda 2030 (2015). Transforming our World: The 2030 Agenda for Sustainable Devel- 
opment. A/RES/70/1.

Akhtar-Schuster, M. et al. (2017). Unpacking the Concept of Land Degradation Neutrality and Addressing Its Operation through the Rio Conventions. Journal of Environmental Management, 195, 4-15. https://doi.org/10.1016/j.jenvman.2016.09.044

Allen, J. et al. (2020). Drought Could Cause Tens of Millions of Ethiopians into a Food Crisis.

https://cruxnow.com/church-in-africa/2020/08/drought-could-cause-tens-of-millionsof-ethiopians-into-food-crisis

Altvater, S. et al. (2015). Ecologic Institute, Legal Instruments to Implement Land Degradation Neutral World in International Law (pp. 1-124). Texte 19/2015.

http://www.umweltbundesamt.de/publikationen/legal-instruments-to-implement-theobjective-land

Asfaw, A., \& Etefa, L. (2017). The Contribution of Non-Timber Forest Products to the Rural Livelihood: The Case of Yayo District, Illu-Ababora Zone, Oromia Regional State, Western Ethiopia. International Journal of Applied Agricultural Research, 12, 157-169.

Asrat, A. (2020). Ethiopia Clearing Forest to Begin GERD Filling. Ethioliving.

Ayana, A. N. et al. (2018). How Environmental NGOs Have Influenced Decision Making in a Semi-Authoritarian State: The Case of Forest Policy in Ethiopia. World Development, 109, 313-322. https://doi.org/10.1016/j.worlddev.2018.05.010

Boer and Hannam (2021). Land Degradation Neutrality and SDG 15. In N. Kakar, \& N. Robinson (Eds.), Implementation of the Sustainable Development Goals (pp. 1-13). (In press)

Boer, B. (2016). Actors and International Law-Making on Natural Resources. In E. Morgera, \& K. Kulovesi (Eds.), Research Handbook on Natural Resources and International Law (pp. 1-23). Cheltenham: Edward Elgar. https://ssrn.com/abstract=2817699 https://doi.org/10.4337/9781783478330.00038

Boer, B., \& Gruber, S. (2012). Heritage Discourses. In K. Rubenstein, \& B. Jessup (Eds.), Environmental Discourses in International and Public Law (pp. 375-398). Cambridge: Cambridge University Press. https://ssrn.com/abstract=2720117 https://doi.org/10.1017/CBO9781139094610.024

Braatz, S. (2003). International Forest Governance: International Forest Policy, Legal and Institutional Framework (pp. 1-12). http://www.fao.org/3/XII/1053-C5.htm

Brunnee, J., \& Dwasi, J. (2006). Mountain, Forest, and Polar Ecosystems. In L. Kurukulasuriya, \& N. A. Robinson (Eds.), The UNEP Training Manual on International Environmental Law (pp. 269-294). Gland: IUCN.

https://www.unep.org/resources/report/unep-training-manual-international-environm ental-law

CBD (1992). 1760 UNTS 79.

Chazdon, R. L. et al. (2016). When Is a Forest a Forest? Forest Concepts and Definitions in the Era of Forest and Landscape Restoration. Ambio, 45, 538-550.

https://doi.org/10.1007/s13280-016-0772-y

Climatekos gGmbH (2020). The Great Green Wall Implementation Status and Way ahead to 2030: Advanced Version (pp. 1-63).

https://catalogue.unccd.int/1551_GGW_Report_ENG_Final_040920.pdf

EBC (2021). Ethiopia: A New Campaign to Plant Six Billion Trees in Summer 2021. http://t.me/EBCNEWSNOW

Eikermann, A. (2015). Forests in International Law: Is There Really a Need for an Inter- 
national Forest Convention (pp. 1-196)? Berlin: Springer.

ENA (2021). Ethiopia: Nation Gains Over 149M Birr from Carbon Trading. https://allafrica.com/stories/202104120770.html

Ethiopian Monitor (2021). Forests to Be Cleared for GERD's Second Filling.

Ethiopian Sugar Corporation (2021). Sugar Development Projects. https://etsugar.com/projects

Ferreira, P. G. (2016). Common but Differentiated Responsibilities in the National Courts: Lessons from Urgenda v. the Netherlands. Transnational Environmental Law, 5, 329-351. https://doi.org/10.1017/S2047102516000248

Fobar, R. (2019). What Is the Convention on International Trade in Endangered Species? National Geographic.

https://www.nationalgeographic.com/animals/article/convention-on-international-trad e-in-endangered-species

Forest Biodiversity (2006). Definitions. https://www.cbd.int/forest/definitions.shtml

Forest Law of China (2019). 3rd Amendment, 15th Session of the Standing Committee of the Thirteenth National People's Congress on December 28, 2019.

Gashaw, G. (2021). Ethiopia Preparing for Third Round Massive Afforestation Campaign. The Ethiopian Herald. https://allafrica.com/stories/202104210513.html

Glover, E. (2020). Pre-Colonial, Colonial and Post-Colonial Forest Legislation, Forest Policies and Practices: Forest Law, Forest Policy and Enforcement Mechanisms for Protection of Forest Resources in Sudan (pp. 1-450). Doctoral Dissertation (Monograph), Helsingin yliopisto. http://urn.fi/URN:ISBN:978-951-51-6793-4

Heflich, A. (2020). An EU Legal Framework to Halt and Reverse EU-Driven Global Deforestation: European Added Value Assessment. PE 654.174.

https://www.europarl.europa.eu/RegData/etudes/STUD/2020/654174/EPRS_STU(2020 $\underline{654174 \_E N . p d f}$

Hoecke, M. (2013). Methodology of Legal Research: Which Method of Law for What Kind of DISCIPLINE? Oxford: Hart Publishing.

Hosonuma, N. et al. (2012). An Assessment of Deforestation and Forest Degradation Drivers in Developing Countries. Environmental Research Letters, 7, Article ID: 044009. https://doi.org/10.1088/1748-9326/7/4/044009

IUCN (2021). Issues Brief: Deforestation and Forest Degradation. https://www.iucn.org/sites/dev/files/deforestation-forest_degradation_issues_brief_202 $\underline{1 . p d f}$

Lee, J. et al. (2018). Economic Viability of the National-Scale Forestation Program: The Case of Success in the Republic of Korea. Ecosystem Services, 29, 40-46. https://doi.org/10.1016/j.ecoser.2017.11.001

Leitner, J. M. (2011). The Expansive Canopy of Korean Green Growth: Key Aspects for Forest Conservation Projects in Southeast Asia. Journal of Korean Law, 10, 171-212.

Maguire, R. (2013). Global Forest Governance: Legal Concepts and Policy Trends (pp. 1-374). Cheltenham: Edward Elgar Publishing. https://doi.org/10.4337/9780857936073

MEFCC (2017). National Forest Sector Development Program, Ethiopia Volume I: Situation Analysis. Addis Ababa.

Ministry of Agriculture (2007). Forest Development, Conservation and Utilization Policy and Strategy. Addis Ababa.

Morgera, E. (2015). Global Environmental Law and Comparative Legal Methods. Review of European Community and International Environmental Law, 24, 254-264. 
https://doi.org/10.1111/reel.12138

NPC \& CSA (2017). Compendium of Environment Statistics. Addis Ababa.

NYDF, A. P. (2020). Balancing Forests and Development: Addressing Infrastructure and Extractive Industries, Promoting Sustainable Livelihoods. Climate Focus (Coordinator and Editor). https://www.forestdeclaration.org/

Peeters, M. (2020). Cycle Green Deal: A Way Forward for EU Environmental Legislation? https://www.youtube.com/watch?v=ZacGDZP_Q1k

Peeters, M., \& Eliantonio, M. (2020). On Regulatory Power, Compliance, and the Role of the Court of Justice in EU Environmental Law. In Introduction to the Research Handbook on EU Environmental Law: The Challenge of Understanding EU Environmental Law (pp. 475-499). https://doi.org/10.4337/9781788970679.00043

Proclamation No. 1065/2018 Forest Development, Conservation and Utilization Proclamation, Negarit Gazette, 24th Year, No. 21, Addis Ababa, 23rd January 2018.

Proclamation No. 192/1980, Forest and Wildlife Conservation and Development Proclamation, Negarit Gazette, Addis Ababa.

Ramsar (2021). Country Profiles. https://www.ramsar.org/sites-countries

Ramsar Convention (1971). Ramsar, Iran, 2.2.1971.

REDD+ Ethiopia (2021). Drivers of Deforestation and Forest Degradation in Ethiopia.

Rio Declaration on the Environment and Development (1992). U.N. Doc A/CONF.151/26.

Ruiz, J. J. (2020). Global Pact Negotiations: Building a Normative Framework for Ecological Sustainability in the Anthropocene. Environmental Policy and Law, 50, 35-46. https://doi.org/10.3233/EPL-200198 https://scihubtw.tw/10.3233/EPL-200198

Schroeder, H. (2010). The History of International Climate Change Politics: Three Decades of Progress, Process, and Procrastination. The Politics of Climate Change, 26, 30-38.

Sommer, J. (2020). Global Governance in Forestry: A Cross-National Analysis. International Journal of Sustainable Development \& World Ecology, 27, 481-495. https://doi.org/10.1080/13504509.2020.1714787

Sotirov, M. et al. (2020). International Forest Governance and Policy: Institutional Architecture and Pathways of Influence in Global Sustainability. Sustainability, 12, 1-25. https://doi.org/10.3390/su12177010

Stevens, C. et al. (2014). Securing Rights, Combating Climate Change: How Strengthening Community Forest Rights Mitigates Climate Change (pp. 1-64). Washington DC: World Resources Institute.

The New York Declaration on Forests (2014). UN Climate Summit 2014.

The New York Declaration on Forests (2019). Goal 3 Assessment: Technical Annex to the Five-Year Assessment Report. https://forestdeclaration.org/images/uploads/resource/2019NYDFGoal3.pdf

UN (2015). Transforming Our World: The 2030 Agenda for Sustainable Development. https://sustainabledevelopment.un.org/post2015/transformingourworld/publication

UNCCD (2019a). The Global Land Outlook: East Africa Thematic Report (pp. 1-80). https://catalogue.unccd.int/1219_GLO_East_Africa_Report.pdf

UNCCD (2019b). The Global Land Outlook, Northeast Asia Thematic Report (pp. 1-88). Bonn. https://catalogue.unccd.int/1218_GLO_Northeast_Asia_Report.pdf

UNCCD (2019c). Forests and Trees: At the Hearts of Land Degradation Neutrality (pp. 1-35). 
https://www.unccd.int/sites/default/files/documents/2019-08/Forest\%20brochure\%20\%20web.pdf

UNCCD (2021). About the Convention. https://www.unccd.int/convention/about-convention

UNEP (2015). Report of the Meeting of Eminent Legal Experts on the Midterm Review of the Fourth Program for the Development and Periodic Review of Environmental Law (Montevideo Programme IV) UN Doc UNEP/Env.Law/MTV4/MR/1/3, para 33.

UNESCO (2010). Yayu Biosphere Reserve, Ethiopia. https://en.unesco.org/biosphere/africa/yayu

UNGA (1992). Non-Legally Binding Authoritative Statement of Principles for a Global Consensus on the Management, Conservation and Sustainable Development of All Types of Forests. UN Doc A/CONF.151/26 (Vol. 3).

United Nation's Climate Change (2021). Land Use, Land-Use Change, and Forestry. LULUCF. UNFCCC.

United Nations Convention to Combat Desertification (UNCCD) (1994). A/AC.241/27.

Urbancic, N. (2020). How Granting Indigenous Peoples' Land Titles Contributes to Forest Conservation in Latin America. Birkbeck Law Review, 7, 26-57. http://www.bbklr.org/7-1-2.html

Wassihun, S. (2020). The Green Legacy Initiative. The Ethiopian Herald. https://www.press.et/english/?p=22877\#

WHC (Adopted 17 November 1972, Entered into Force 17 December 1975) 1037 UNTS 151.

WWF (2021). Desertification and Forest Degradation. https://www.worldwildlife.org/threats/deforestation-and-forest-degradation

Yilak, D., \& Debelo, G. D. (2019). Impacts of Human Resettlement on Forests of Ethiopia: The Case of Chamen-Didhessa Forest in Chewaka District, Ethiopia. Journal of Horticulture and Forestry, 11, 70-77. https://doi.org/10.5897/JHF2019.0576 